\title{
HEARING RELIGIOUS MUSIC. THE SUBJECT-OBJECT RELATIONSHIP OF THE LISTENER AND THE PIECE OF MUSIC IN A CONSUMPTION ERA
}

\author{
OANE REITSMA*
}

Protestant Theological University, Amsterdam E Groningen

\begin{abstract}
In a concert hall, the attitude of the audience focusses on the formalistic aspects of music. In religious rituals, music is a means of leading the hearer to a spiritual experience. What happens when music, meant originally for a liturgical purpose, is played in a concert setting? Gadamer shows, with his conception of Verwandlung ins Gebilde, that an art work is never static, but carries a depth in itself, which is connected to an artistic ingenuity throughout centuries. In this 'depth' lies the connection to the listener, which is broader than a mere aesthetical one. On the other hand, music in itself has a strong 'theatrical' side, which can easily surpass its contemplative aspect in consumer culture. It appears that this aspect, in combination with the formalistic-aesthetic approach of modern museum culture, of which concert culture is a part, made the hearer become almost 'deaf' to the religious content; because a concert practice focusses primarily on entertaining the hearer, $\mathrm{s} / \mathrm{he}$ is not able to engage in the music as a source of spiritual edification of the soul. Nevertheless, Gadamer's conception of play makes us be aware that there will always be new, unexpected ways in which the truth comes into being in the interaction of a piece of music and its hearer. In order to create such a reality, it is necessary to turn to new and renewing hearing practices, where the play between music and the hearer has a wider range of musical experience than the mere formalistic aspect.
\end{abstract}

KEYWORDS: art, religion, religious music, play, Gadamer

\section{Concert and Liturgy in One}

On a wintery evening in January 2019, I attended a choir concert in the Music Hall of Enschede, a city in the eastern Netherlands. The concert offered an A Capella musical program entitled 'Dark Russia', which consisted of early Russian church music, viz. excerpts from an anonymous piece of Russian medieval requiem-Great Panikhida. The concert, a performed liturgy, began with the Introit in which the Heavenly King, the Comforter and Spirit of Truth was called 'to clean us from our impurity and save our souls'.

OANE REITSMA (PhD 2014, VU University, Amsterdam) is a theologian and a minister in the Protestant Church in the Netherlands (PKN), as well as associated researcher at the Protestant Theological University in Amsterdam/Groningen specializing in religious music, theological aesthetics of music, and art. Email: oanereitsma@gmail.com. 
While singing, the soloist walked slowly from the rear of the concert hall, carrying a lantern. He carefully placed it on the floor as he reached the stage. While singing the first Halleluja, all the singers joined the soloist, emerging on the stage in slow movement and making a half circle, in front of which the choir conductor stood. Each of them lit a candle on a high standard, until light shone from all directions of the stage, in order to create an intimate abbey-like atmosphere. Throughout the requiem, the text carried an attitude of humility to God, praying for mercy for sinful souls. The audience was, thanks to a booklet of this concert program, able to follow the text along with the performance, although the dimmed light made it difficult for the eyes to see the small printed text properly. When the performance ended, the conductor held a short silence after the last sounding words 'eternal memory', after which the audience burst out in applause as usual at a concert.

What is exactly happening at this concert? A medieval liturgy is performed in a modern concert setting, at a modern concert hall. At the same time the performance tries to create an atmosphere akin to a monastic one, by adding elements like candles and procession of the-only male-singers to it. The audience nevertheless reacts in a way which is predictable: applauding for the performance, but seemingly not adopting the humble mood which the sung texts just tried to evoke. After the performance the audience immediately seems to return to its usual 'audience attitude'. The sung text did not fundamentally seem to have changed their lives in a religious way-apart from the fact that they experienced a new musical event, but that seems to be an aesthetical experience rather than a religious one.

An ancient liturgy is performed as a concert, whilst at the same time concert culture also contains its own 'liturgical' elements, in the sense of a fixed order of actions (Söhngen 1978; Johnson 1995; Smithuijsen 2001). The concert as such is a kind of 'play', in so far that several actors voluntarily engage in an event which is set by certain prescriptions. But another play is performed within this play-a kind of stage play in which choir members act as medieval monks. At the same time it is fully clear that they are not monks, given their modern suits and their emphasis on a beautiful performance instead of an active engagement in an act of prayer. The audience voluntarily chooses to engage in this play-in some way to be disguised, as they recognise a monastic practice, knowing at the same time that it is not real-and they even enjoy that!

\section{Hearing Practices of Religious Music}

This article attempts to elucidate the hermeneutical tension which comes into being when people hear religious music in art practices, where consumer culture opposes religious experience. Although many practices of 
hearing music have evolved in electronic and digital times (I prefer the term 'hearing practices' to 'listening practices', because the practice of listening presupposes an intentional act, whereas music in most practices is more or less coincidentally 'heard' nowadays, Scruton 2015: 75), I will consider the two hearing practices which have been dominant for a long time with regard to religious music: that is, liturgical practice and concert culture. While my focus is on the latter as an art practice, it is helpful to look at the former, to elucidate concert culture by studying its counterpart, thereby bringing the complicated way in which religious musical experience and aesthetic values relate to each other to the front. Religious experience has a dominant nature in itself, for it captures the totality of human existence (not only the musical experience). On the other hand, the consuming attitude of concert culture became dominant in that most things which concern human life are experienced as sources of entertainment, in which the consumer has a free choice to make. Both practices are contradictory to each other. In the musical practice of religious ritual/liturgy, the music takes the lead over what is going on, as it overwhelms and grasps the totality of the 'hearer'. But in a musical concert, the listener has the freedom of choice to engage in an act of listening to the music and to become aloof from it at the end of the concert. Now, when the religious music becomes part of concert practice, is the power of religious music stronger than the freedom of choice of the hearer? Is the hearer able to make himself aloof again? Or did modern concert culture, focussing on personal 'enjoyment', put the hearer as a consumer in such a central position that the hearer even became 'deaf' to the content of the music? In other words, is it the music which takes the lead in listening experience, or is it the attitude of the hearer? Does the object predominate the subject, or is it the other way around? Put this more theologically, in liturgy the presence of the Holy One takes the lead over the gathered, even when it seems that the people gathered start to 'act' first. But how does this work in concert culture and in the example of the concert in Enschede mentioned above, where religious music becomes part of secular concert culture?

This theme can be cleared up with two conceptions which Hans-Georg Gadamer uses in his Wahrheit und Methode, namely, the ästhetische Nichtunterscheidung and the Verwandlung ins Gebilde. We will first consider these conceptions of Gadamer in order to bring the issue in question to the front in hermeneutical terms. We then will take into account several aesthetical and theological viewpoints, to shed new light on this issue.

\section{‘Ästhetische Nichtunterscheidung' and 'Verwandlung ins Gebilde'}

In his hermeneutical theory of art, Gadamer develops two on the surface contradictory conceptions about the relationship between object and sub- 
ject, the art work and its perceiver. The first conception is the 'aesthetical non-differentiation' (ästhetische Nichtunterscheidung), which criticizes the distanced attitude towards the art object in modern museum culture. The second conception is the 'transformation into structure' (Verwandlung ins Gebilde), which sees the art work as a locus par excellence to bring a new insight to the front. It would be too easy to say that the first conception centres on the position of the perceiver, whilst the second one focusses on the ontology of the art work. For hermeneutics focusses exactly on what happens between object and subject, as Gadamer specifies in his theory of the 'fusion of horizons' (Horizontverschmelzung). In this case, he keeps the two conceptions together with his central conception of 'play'. This play character reflects an on-going happening between subject and object, art work and its perceiver, where truth comes into being repeatedly, which I will explain in the following paragraph. Therefore, whether the focus of understanding may be object or subject, the other side of the spectrum plays along. This is the very focus of the present article too: that is, the relationship between art work and perceiver.

In his Wahrheit und Methode (1960) Gadamer criticizes Kant's theory of aesthetics which focuses overtly on subjectivity in emphasizing his conception of Geschmack (Gadamer 1960/1990: 48-50.94-106). For Kant's emphasis on the 'idea' of the art work is, unintentionally, led to a division between the content of the art work on the one hand and its formalistic features on the other (Stoker 2019: 40-42). In the formalistic-aesthetic approach which emerged after Kant, the latter plays the upper role because Kant's aesthetic judgement was interpreted as not considering the 'content'; instead, it only judged the superficial external elements of the object that gives one pleasure. In this light, the art work becomes abstractive, being separated from its original profane or religious dimensions (91). It loses its original place in the world to which it belongs. Or, as it were, the religious and aesthetical dimensions are torn apart. A case in point is the altarpiece in a museum, or a Bach cantata in a concert hall. In such a context the art work is intended to give pleasure to spectators or audience, not to praise and glorify God or to edify the religious congregation.

In music philosophy, this aesthetic attitude is most fundamentally criticized by Goehr, who argues that Bach did not compose his St. Matthew Passion as a musical work according to the 'work concept' as termed, interpreted and experienced nowadays (Goehr 2007: 8). According to the so-called work concept, musical works are understood in terms of independent, autonomous entities, which are referred to as an opus number. The music does not serve any which is outside the music itself (religious, social, academic, domestic or profane); but the context in which music is performed serves the music itself as absolute and central phenomenon. Goehr explains her 
'separability principle', the principle of concert culture which extracts the music from the common, the worldly and the every-day life, which Gadamer precisely criticizes as aesthetical differentiation (ästhetische Unterschei$d u n g)$. By focussing on the concert practice of nineteenth-century pianism, Hamilton even adds an 'aesthetics of perfection' to Goehr's position, the aesthetics in which a musical piece is ideally surrounded by silence (Hamilton 2008: 193-199), like a painting hanging on a white wall in the museum, isolated from any circumstantial distraction. To my mind, the audience's applause before and after a concert illustrates what Gadamer's ästhetische Unterscheidung is about (Reitsma 2016: 236). The audience applauds for the achievement of the performers, or at most for the composer's, but the applause, which always follows the fixed order of its own profane 'liturgy', does not relate in any way to the content of what is just being heard, exactly for that reason.

Gadamer, however, defends aesthetical non-differentiation (ästhetische Nichtunterscheidung) which illustrates how his hermeneutics as a whole works, for human understanding is never isolated from the historical and cultural context in which s/he presides. There is never a gap between the individual as the subject of interpretation and the object that surrounds the subject. The horizon of understanding on subject's part and the horizon of the object to be understood melt together when the subject comes to the act of understanding or relating to the object. Even the museum culture, of which modern concert culture is a part, reflects not a universally 'objective' aesthetic principle but forms a historical phenomenon itself. It is a place where the fusion of horizons comes into being in the dynamic form of active perception.

In his Die Aktualität des Schönen (1974) Gadamer is much less critical about Kant. This is understandable, because in this article, which is a later elaboration of the paragraph on art in Wahrheit und Methode, Gadamer emphasizes the other side of the same principle about art: that is, his conception of what he earlier called the Verwandlung ins Gebilde. Gadamer praises Kant's achievement of connecting the individual art work with a deeper, universal value, called 'beauty' ('free beauty'; Gadamer 1974/2001: 111). Each individual art work which has the power to carry this value is the product of a genius. This acknowledgement of ingenuity is a continuance throughout ages. It is the only objective and universal aesthetical principle of true art (Gadamer1960/1990: 63; id. 1974/2001: 112-113). Kant does not merely focus on the superficial meaning of forms and taste (derived from formal aspects), but he emphasises the depth of ingenuity above all. In every art work in which this depth can be noticed, play has been transformed into structure (Verwandlung ins Gebilde). The energeia turned into ergon (Gadamer 1960/1990: 116) and the art work obtains a well-defined identity 
(Reitsma 2016: 231-234). The 'transformation into structure' is a 'transformation into truth' (Gadamer 1960/1990: 118). The work has a goal in itself. An art work elevates (Aufhebung) the reality into the realm of truth.

\section{Liturgy Concert Revisited}

As said, both conceptions, the ästhetische Nichtunterscheidung and the Verwandlung ins Gebilde, look contradictory at first sight. The ästhetische Nichtunterscheidung seeks a practice where there is no distance between subject an object. The 'art work' should not be taken away from its organic context. The Verwandlung ins Gebilde, on the contrary, carries notions of nineteenthcentury art philosophy, where the art work has a well-defined identity, apart from any context. We do not do justice to Gadamer in this analysis, because he keeps the energeia (i. e. the act of making an art work as play process) and the ergon (i. e. the more or less fixed result of the play process) closely together. Moreover, the recognition of the truth in an art work is an active process between subject and object. The truth 'flows' through history and emerges in art works, but it is as such never fixed to a single art work. Thus, Gadamer's understanding of Gebilde is much more fluid than one might think at glance. That is also why Gadamer does not fundamentally distinguish performing arts from visual arts. The ongoing emergence of truth as a process is essential to Gadamer's hermeneutics, regardless the form of art under discussion. In conclusion, the Verwandlung ins Gebilde should always be understood as a transformation which comes after the awareness of the ästhetische Nichtunterscheidung.

Although Gadamer keeps both conceptions together with the word 'play' as a basic human attitude, following Huizinga's Homo ludens, let us postpone this awareness for a moment; before we move to the theme of play, it is necessary to draw one step backwards and to consider the first intuitive tension between the two concepts.

Looking at our example of the liturgy concert as described at the beginning of this article, we again raise the question about what is happening there. A play is played. When the first soloist enters the concert hall, we see an example of what could be seen as ästhetische Nichtunterscheidung. The concert does not begin from silence or the usual applause of the audience when the performers appear on stage. In this case, it starts quasi spontaneous: the lights still have to be lit and the soloist enters as if he enters on his own an empty chapel in a monastery. Moreover, the performed music is not a welldefined musical work. Excerpts of an ancient requiem, partly reconstructed, are sung as if they are part of a solemn prayer meeting, but not an entire musical composition from the beginning to the end. Performers play as if they sing in a 'less organised' prayer setting. 
At the same time, the way the listeners respond to this musical happening is typical of concert audience. They do not as much engage in the prayer as they do in the aesthetic act. Actually, the modern aesthetic attitude is a 'play-in-denial', in that it experiences the art work as a whole, while focussing only on the external, formalistic side of it. Obviously, there is a tension between the content performed and the way the form is experienced. In this case the aesthetical differentiation is even stronger, precisely because it concerns religious music; the differentiation between musical form and religious content is sharper than in the case of a performance of non-religious music. Are the listeners in a concert setting in any way able to hear the deeper (religious) meaning of the art work as an integral part of their own spiritual life? Or are they merely able to perceive the music aesthetically, i. e. as an audience? Thus, in conclusion, the question remains as follows: what is dominant in the interaction of music and its hearers when religious music is 'performed' in a concert hall? What is happening in the interaction between subject and object? Let us now have a look at some thoughts about the nature of religious music and religious practices, in order to get to know more about concert culture by turning our ears to the opposite, i. e. liturgical practice.

\section{Liturgical Music}

On the basis of ancient and medieval authors, Kim distinguishes two types of religious music, in terms of the play character of music: that is, contemplative music and theatrical music (Kim 2013: 238). The word 'theatrical' does not imply 'theatre' in the modern concert-like sense here, but music accompanying public ritual, like in liturgy. It supports the external, performative side of the ritual. The second type, contemplative, is music on which the hearers meditate in order to bring their souls closer to God, like monophonic liturgical chant (239). It helps to develop the inner engagement of the believer in the ritual and in his/her faith in general. Most forms of religious music are somewhere in between those two types. 'Taken as a whole, however, a public religious ritual or liturgy itself is prone to be theatrical in that it is visually displaying and involves both performers (presiders) and "audience" (liturgical assembly)' (239).

Although Kim admits that, from a theological point of view, congregation can never be a passive, observing audience but is rather engaging actively in liturgy, not seldom 'priests, choirs and organists play their roles in 'leading' the liturgy', which causes the congregation to turn into audience (239). This was not only practice in the Middle Ages, when parishioners became spectators in the Eucharist ritual, but it happens especially in modern consumer culture as well. Interestingly, here comes the distinction between form and content also to the front, although it is based on sources 
that existed long before modern concert culture came into being. 'Although the content of a liturgical text is crucial, what often moves the audience is music rather than text. [...] Music can be more effective than words in arousing the "affection" (affectio) [of hearers]' (Kim 2013: 239). Kim thus states that there is a power in the music itself which leads the hearer to an engagement with the music, rather than that listening to the music leads the ears to the text. This is an intrinsic power which is precisely located in formal aspects of the music. Many fixed liturgical texts, like Mass texts, have been set in various musical styles. But it is the type of music which moves the hearers. This becomes clear in the Affektenlehre in Baroque music, where a certain feeling is connected to a certain musical pattern which 'affects' the listener (240). In Bach's cantatas and passions, as in Telemann's or Schütz's, the arias appeal to the listener more than the recitatives do. Alongside melodies of the solo instruments, the vocal melodies remain stronger in the listener's mind than the text, which is especially true when we compare it with texts that are only read aloud or silently, as it is known from hymn singing that a melody remains stronger in the mind than its text.

Immink takes the same approach as Kim, when he regards liturgy in the first place as a performance (Immink 2014). Regardless of the fact that he focusses on Reformed liturgy, he emphasizes that liturgical worship is in the first place an act of the congregation. 'During the service the human self becomes active' (22). 'Besides that worshippers will expect God's activity' (23). Whether God should be seen as the first actor, or human beings, which is a theological matter, it is important for us to notice that, phenomenologically speaking, worship consists of series of acts, and acts are, simply, performed'. What else could the ontology of liturgy be then? There is no entity 'behind' the 'acting'. All participants-the congregation, the clergy, and God-come into being in the act of performance. In the performance of existing texts and hymns, in most cases, a renewing reality is presented in and through the performance. '[T]he worship service focuses on the connection with the decisive salvific revelation from the past and the active and impelling presence, which is expressed in the performance' (24).

Is this also applicable to a concert, that the 'happening' comes into being in the act itself? In my opinion this is, indeed, the case, to a great extent. The major difference between concert practice and religious rituals lies in the intention of the participants. In a concert context, there is no expectation of any transcendent aspect, apart from the transcendent experience in (and of) music itself. Thus, even though religious music is being played, the formalistic aspect goes first. The term 'religious music' already makes clear that the 'religious' aspect is seen from an external point of view. In conclusion, apart from the fact that music in nature already tends to lead the ear and the heart to the music per se rather than to a (textual) content, even in a 
liturgical context, in a concert performance this effect is twice as strong, even when the music performed is religious in content. The audience attends the concert for an aesthetic experience and voluntarily goes into a quasi-religious play in order to gain an aesthetic experience. This is part of the erosion of Christian faith in a secular age. In the context of mere 'cultural Christianity' faith is only known from its formal, exterior side and has no more connection with the inner spiritual life.

\section{Back to Play}

Finally, however, let us not only focus on the division between religious and aesthetic experience, but also consider the more nuanced way in which Gadamer connects his two conceptions, the ästhetische Nichtunterscheidung and the Verwandlung ins Gebilde, by using the concept of play. The Verwandlung ins Gebilde (transformation into structure) tells, after all, more about the 'transformation' than about the final 'structure' (of the art work). In other words, Gadamer presents a very dynamic concept of art, which is possibly even open to religion (better: religious experience). '[I]t becomes clear why starting from the concept of play is methodologically advantageous. The work of art cannot simply be isolated from the "contingency" of the chance conditions in which it appears [...]. My thesis, then, is that the being of art cannot be defined as an object of an aesthetic consciousness because, on the contrary, the aesthetic attitude is more than it knows of itself. It is a part of the event of being that occurs in presentation, and belongs essentially to play as play.' (Gadamer 1960/1990: 121-122). Therefore, the play character makes us be aware that art is open-that the energeai, which is the Kantian 'idea' of 'free beauty', or Gadamer's concept of 'ingenuity', keeps flowing through history even when the music has been fixed into an ergon. This openness does not only yield for the piece of music, but also apply to the hearer as well. It is an openness to reality beyond what is, literally, heard-let us call it transcendent. But there is one condition: the subject should be open to the transcendent realm. As long as de subject's longing is not a religious one, as long as s/he has no antenna for religion, the art consumer will only be moved by the formalistic aspects of the musical performance, even though the formalistic aspect can have many transcendent features. Perhaps, he recognises some analogy between music and text in terms of how the music supports the text, or, vice versa, how the texts lead to certain musical forms, and enjoy being able to discover that in the act of listening. In our example, however, mainly the voice of the music will be heard, not the voice of God. Nevertheless, the question remains what is more dominant. The subject's intention or the object's persuasiveness.

It is J. Kramer who gives the clearest view on the subject-object relationship in this issue, presenting a theoretical framework for the relationship 
between religion and play. He analyses the way in which several philosophers use a concept of play in relation to religion; inclusive as well as exclusive relationships between them, in addition to reciprocal, incompatible, and transformative ones. In doing so, he develops a highly theoretical framework in which he speaks about play, religion and transcendence as abstractions. Kramer's presupposition is not far from Gadamer's view in that both 'religion and play are forms of expression of the human being's relation to reality as such' (Kramer 2012: 15-16, 244).

Each of the two expressions articulates a form of transcendence. The two forms of transcendence nevertheless differ from each other. In his own understanding, the religious human being is more transcended by reality than reality being transcended by the human being at stake, according to Kramer's central argument. In other words, human beings experience themselves as an integral part of a bigger whole, which is called reality-whether it be visible or invisible. In the case of play, not focussing specifically on religious experience, this mechanism works in the opposite way: here the human being himself is in control. He has a free choice to go into the play or not. Religion can lead to play, play can lead to religion, but Kramer's main point is that the religious transcendence is experienced as a unity, and the transcendence of play as a duality. For the religious transcendence has a surplus value to the transcendence of play, it will always be dominant and the turn of the unity into duality is always more included than the other way around. (Transcendence is understood in a theoretical way here, not drawn up to specific religious views, but as an expression of the human feeling of dependence on a 'bigger realm'.)

This leads to Kramer's creative definition that 'religion is the expression of the reality that transcends human being' (28) and 'play is the expression of the human being who transcends reality' (40). The focal point of religious experience lies outside human being, while that of play within human capacity. As an example of the latter Kramer borrows an example from Plessner, who connects laughing with play. During play, a human being plays with reality and lets reality play with him/her. The understanding that reality cannot really play with us, unless we give it permission, makes people laugh. In the act of laughing a human being takes back control over the play (51).

In my opinion this is precisely what happens in concert hall when the audience is applauding. The audience takes back control over reality and totally breaks the enchantment in which the musicians on stage-or the music itself!-just took the lead. In applause the audience shows its appreciation, enthusiasm even, to the performers, but there is no engagement with the content of what is just heard. Indeed, this is a dual relationship. 


\section{Towards Music as New Religious Play}

This article began with an example of a performed liturgy in concert setting. Music has the intrinsic power of grabbing the hearer's attention in the direction of the musical form rather than the (in this case religious) content. This is even more the case in the concert setting because it is a closed setting, full of expected behaviour. So is an 'expected listening horizon'. Concert hall is one of the hearing practices where the distanced attitude to art, the ästhetische Unterscheidung, is at its clearest. The choice of musical repertoire in the example discussed is not uncommon for a concert; but the form of performance is less common-it is already a kind of play itself. The audience was intentionally led into a religious setting, although it was immediately clear to the audience that the religious setting of the performance was a play (in its narrower meaning: not real). This example leads us to the question about the relationship between religious music and modern, secular concert culture. What is stronger between the subject (who is secular audience in concert setting) and the overwhelming object (the performed music)?

Gadamer teaches us that, judged from the point of view of play, the musical reality is always larger than what happens between subject and object. Even where consumer culture is dominant, there is always a fundamental openness to new experiences, like religious experiences, even when they are unlikely because of the dominant context which focusses on form. Hidden within the form is a depth that constitutes an ingenuity which appears in art throughout centuries. A Christian theologian would call this the Holy Spirit. After all, religious music has always been more than entertainment: it was meant for edification and has a strong ethical aspect (Kim 2013: 246). Given that, there is always an openness to a different experience than just a horizontal one. Kramer shows us, from a more theoretical point of view, that the nature of religious experience is dominant over mere playexperience (e.g. of the concert hall), because the subject experiences him/herself more dependent to a 'bigger whole' (like God), whilst in a play setting the subject him/herself is independent. The applause, by which the audience takes back control over the event, can be seen as an example of this independence. But it can also be seen as an example of the opposite claim, namely that the applause proves that music has an overwhelming power to lead the hearer away from his own consciousness to a bigger realm. In that case the audience feels the need to take back control, and does so in the applause-as if there is a sign of fear of letting control go.

How can musical practices find a way out of the lock in which modern concert culture makes the hearing experience just formalistic? How can the focal point of a musical experience be moved back to its original position, beyond the duality of listener and music, in order to become again a spiritu- 
$a l$ (or even religious) musical experience? In the first place, the nature of music is at stake here, namely, its theatrical and/or contemplative character. Kim already makes it clear that the balance between both characters is nuanced: 'Baroque passion oratorios are theatrical and operatic in terms of musical styles, yet when listening to them the audience is supposed to contemplate on the meaning of libretto (the passion story) amplified by the dramatic music' (Kim 2013: 239). This points out that the answer lies in the nuance of the music itself. But possibly the answer lies even more in the nuances of the hearing practice, that is, the way (and place) music is played. Several scholars, searching for the spirituality in and of music (Cobussen 2008), or pleading for 'embodying arts in Christian worship' (Benson 2013), take their starting point in musical improvisation.

Stoker regards the exhibition of (visual) art as a religious practice, dependent on the way the art works are exposed (Stoker 2019: 279). When the art experience emphasizes only the aesthetical aspect of the art work, then the art becomes 'elitist'. But when, by an act of disclosure, an existential interaction can be made between the art work and its perceiver, it becomes a matter of religion or spirituality $(264-266,280)$. The same could be true of music. The settings and circumstances in which concerts should be arranged are crucial for making musical experience spiritual. Subtlety and nuance is necessary for transforming a musical practice which is able to transform the hearer and to elevate his experience to a new understanding, that is to say, not to a new understanding of the piece of music, but to an existential new understanding of himself. Perhaps, part of the answer to the transformation of hearing practice, indeed, is hidden in improvisation. Improvisation is exactly what was missing in the concert in Enschede, even though they tried to show the opposite: a 'spontaneous' happening, but excessively 'under control'.

\section{Bibliography}

Benson BE (2013) Liturgy as a Way of Life: Embodying the Arts in Christian Worship. Grand Rapids, MI: Baker Academic.

Cobussen M (2008) Thresholds: Rethinking Spirituality Through Music. Aldershot / Burlington: Ashgate.

Gadamer H-G (1960/1990) Wahrheit und Methode: Grundzüge einer philosophischen Hermeneutik, Gesammelte Werke Bd. 1: Hermeneutik I. Tübingen: J. C. B. Mohr (Paul Siebeck).

Gadamer H-G (1964/2001) Ästhetische und Religiöse Erfahrung. In idem, Kunst als Aussage, Gesammelte Werke Bd. 8: Ästhetik und Poetik I. Tübingen: J. C. B. Mohr (Paul Siebeck), pp. 143-155. 
Gadamer H-G (1974/2001) Die Aktualität des Schönen: Kunst als Spiel, Symbol und Fest. In idem, Kunst als Aussage, Gesammelte Werke Bd. 8: Ästhetik und Poetik I. Tübingen: J. C. B. Mohr (Paul Siebeck), pp. 94142.

Goehr L (2007) The Imaginary Museum of Musical Works: An Essay in the Philosophy of Music, revised edition. Oxford: Oxford University Press.

Hamilton A (2008) Aesthetics E Music. London/New York: Continuum.

Immink FG (2014) The touch of the sacred: the practice, theology, and tradition of christian worship. Grand Rapids, MI/Cambridge: William B. Eerdmans Publishing Company.

Johnson J (1995) Listening in Paris: A Cultural History. London: University of California Press.

Kim H-A (2013) Homo ludens, Music, and Ritual: The Play/Non-Play Characters of Religious Music. Questions Liturgiques 94(3-4): 220-246.

Kramer J (2012) Religieuze eenheid-speelse tweeheid: De mens en zijn werkelijkheid als referentiekader voor religie en spel. $\mathrm{PhD}$ Thesis, VU University Amsterdam.

Munck M De (2014) Muziek en mystiek: Naar een filosofie van muzikaal engagement. In Reitsma O, Gerwen R van \& Munck M De (red) Muziek ervaren: Essays over muziek en filosofie. Budel: Damon, pp. 58-74.

Reitsma O (2015) Religious Music as Child's Play: Gadamer's Hermeneutics and Instrumental Music. In Stone-Davis FJ (ed) Music and Transcendence. Farnham/Burlington, VT: Ashgate, pp. 177-193.

Reitsma O (2016) Musical Works as Higher Times. In Zemmin F, Jager C \& Vanheeswijck G (eds) Working with 'A Secular Age': Interdisciplinary Perspectives on Charles Taylor's Master Narrative. Berlin: De Gruyter, pp. 229-244.

Scruton R (2005) Music and the Transcendental. In Stone-Davis FJ (ed) Music and Transcendence. Farnham/Burlington, VT: Ashgate, pp. 75-84.

Smithuijsen C (2001) Een verbazende stilte: Klassieke muziek, gedragsregels en sociale controle in de concertzaal. Amsterdam: Boekmanstudies.

Söhngen O (1978) Theologische, geistes- und musikgeschichtliche Voraussetzungen der Entstehung der außerliturgischen religiösen Musik im 19. Jahrhundert. In Wiora W, Massenkeil G \& Niemöller KW (hrsg) Religiöse Musik in nicht-liturgischen Werken von Beethoven bis Reger. Regensburg: Gustav Bosse Verlag, pp. 19-45.

Stoker W (2019) God opnieuw verbeeld: Een theologische kunstbeschouwing. Almere: Uitgeverij Parthenon. 